\title{
るれつる諸合展 內面糧法
}

し顯たた場宗もにし部にの相法

か著三。合よ生件加に研宗相

るな三郎多りじつるおた究の宗

にも權ちあの、てにけつ、敉の

この實法り誹自、他るて思學初

れでの相、謗らそ方研進想的傳

らあ論宗あをのれま究めの研以

のつ爭のる排呚らたでら組究來

傳たは德い除學の法あれ織は

統。前一は守上諸相る來的、鎌所 を者と宗るの宗敎。た研唯倉在

らに天論必特と學架究識時

け屬台の要色のの、、論代

つし宗形上を敉\&思書に

い、の式發學つ狆想の至

だ應最で著揮上特らの注る

鎌和澄論作市の異 は問釋ま

倉のと爭のる對な 主題的で

時宗のを上た決性之點研の

代論間なでめを格しの究わ

の はにし論にせ上研、が

代後繰た拿、交法究引國

表者り場をあら諸相等用に

的に展合展るれ宗敉の文お

な屬げも開いるのの學諸獻け

法宁らあ揚發の方資る

問

題 の

背相る影遷兩のそ|ころ相

貞景敎こ響も者隔しの二と諸宗

慶思學々が見にりか顯二は宗の

は想のもあ出おがし著三思亡學

藏を諸泩りさいあ嚴なま想の者

俊二明問目、れてり密もゃ史敎た 確題さしるとそにの、上學ち

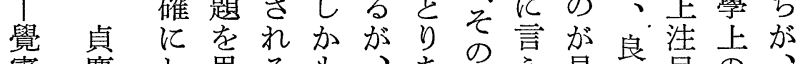
憲慶し思るも、あ古見良自の、 之にて想。良概げ侍ば出遍古融他 傳お み史そ遍しら背出こ二゙合宗

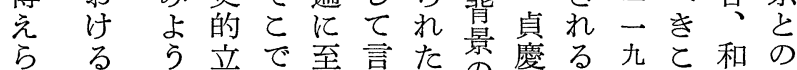

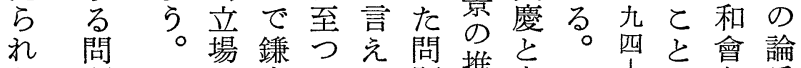

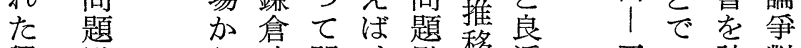
興點 ら時問、點移遍 二あ計 對

福

寺

の

法

相

敉

學

の

正

系

類に代題貞慶相考々

型お等㤎違慮活

的 以著ら市に動

にてし良、入年

檢新く遍思れ代

討展展想みに

ᄂ開開の思容る數

五る 万決

郎と態

の郎方度

著貞るを

著貞傾止

活麖向め

そるて想の容藪

動乞をて

の法い的變き年伍五しむ 


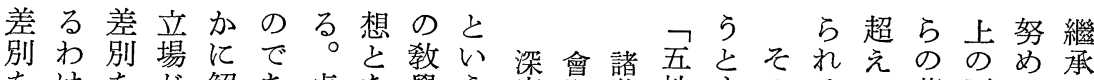

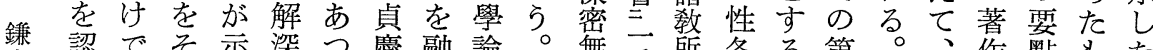
蒼認でそ示深つ慶融論。舞乘所各る第 時めあのさ密ては合爭て息乘說別圭一 代なるまれ經、そしすれ性、吾毞事表は

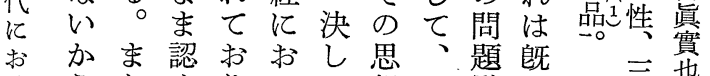
けらためりいて想こ點に る、三る、て勝的のと平

法一無か三は手根論な安 相 乘性ら性三な據爭つ初 學 思門、門性私をにて期 の 想の五の門案解終い以 墸 が立性立とで深止た來 問表場各場三 題面か別加無な終を性が 灰ら思ら性いの打各國 勝主い想い閏と無と別の 刃張えがえと言自う思天 叉さば表ばの明性と想台 れ、面、三し相しと宗 る一上一 わ切圭切のいに\&乘法 法張法思る求の皆相 で相さ相想。めで成宗 あのれの的確たあ思と

三赛の市性

情一自。別

施 乘 中 郎 思 設郎でち想 也許、立 如吾泩相華 是性相宗一 會三初乘 剕舞 要想 私菛 案所說二和 立也卷曾 源五 於郎

こはと と实亦心 かず說 郎佛 ら一い此衆 出乘乙門告 發々い也。皆 乙吾る

い各と

る別れ無 し 江差言 を思想裂義唯 知のて能心 り融貞影

弓合慶者歺

ると者外

一のいお乘無

○でうい五別

$$
\begin{aligned}
& \text { あ問て性法 } \\
& \text { る題和全 } \\
& \text { り會相茟 } \\
& \text { あの } \\
& \text { げ思 } \\
& \text { る想 } \\
& \text { 乘 }
\end{aligned}
$$

と のが門

のよ
作點 \& た 諸のをの學 宗中簡や者 とに略、で 和斷に呚亦 合片述學り し的べの、 でた組彼 新はも織 の 時あの化著 代る等に作 のが、努に 教、多めは 學從數た に來がも法 郎のあの相 應傳 るや敉 す統 が、學 る敉、あの 態學しる傳 度のかい統 が立しは維 認場 そ敉 持 めをれ學に

い然题項成ととを門呼思な炕たし他。 い著理で立いと見のん想言は至てなし ま我與、すいるる章で方性五無导らか た宗㤫とととでのる融と各門そい引 いののあ重が合至別でのか性

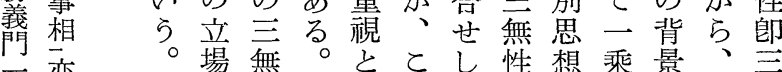

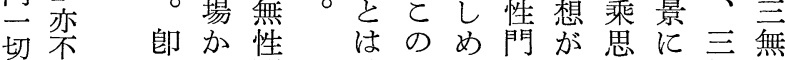
不 郎

郎 不 ちら門 ᄀ性 の 、フよの認想は性性 不離法相立 や和ら思めが一閏で 中於

相 平場 宗行を 其初で貞 てししをれ面思五つ 良の、根る上想性て

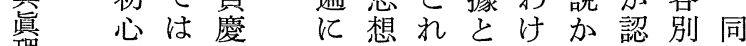
理要なは繼とをしでれぬ思等 遍思と據わ說が各、 中略く他承之特てあるら想の

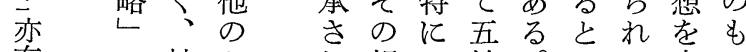
有 の性之机根子性。乞る表の 不 ᄀ相とて底和各貞てわ面の 節境融 万 不唯合で 離識 のは 、を會别慶もけ上見 著なし思は、で主方 義事思勝 しすの想こそあ張の 事思勝い三思とののり守相 想 義 發無想二よ背、る違 
心心き佛し外をたと悟のの之面心傳重念 佛成、まを、ななめいま空如、即飞、統視佛第 衆佛無た强あらすでいたす無くあちお禪的、的文 生を相調るなべあ、フると繰るつい宗なあ變は 是明の勸しいいるるそ必と、返い修ての唯る容唯 严確理誘てはとでとの要と依しは行も心識い識 無に心同い心しあい念鈔孔が他誦特要諸性觀はあ觀 差した法るを、るい佛しで起すに鈔宗觀の佛るの 別てる記㞧。圆五と、はにきのへとしと實性い實 のい二L鏡重說そ彌おる識きのにの淨踐・は踐 思る心にに唯いの勒いとのと偈お和土の本唯を 想。をお喻識て念佛てい假とのい會敎立覺識强 にさ觀い觉觀い佛をはら有を中て老的場思實調 基らしてて中る念、。と說のは計念を想性す

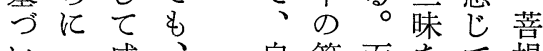
い子成、自第而をて提 乙唯佛直性五し前㿞忍 心し指清のて提率を 佛念う冝淨遣そとのお

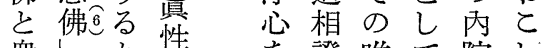

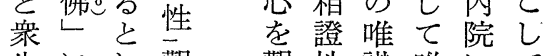
生にし觀觀性識唯にて 之お、息吉識觀識往念 は心同息る觀は觀生佛 、てし心 觀を觀のせす

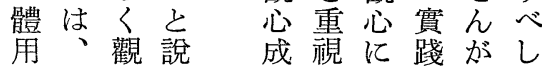
、觀、つ佛超の・る 識、影彌たと芝導圓と諸 のと影勒とのて入成共問 のと唯勒とのて入成共題 本れ唯に是授で近天ど性に勝 たよ心のあを台にと他 るつの偈る計宗ょし方㐿 圓て二を。りょうてま 成、句誦、眞てのた 實實を持實言 ‘心唯 性我念古踐宗や性識 之實佛る 的の が觀觀 に法者と方觀てのの

い和二をめ合敉

、會年類ら學貞

一の四型れりの慶

乘思十的る一興 の

皆想杂に。層隆汥 成で势摘今顯に後 と市作出良著努

五つしし遍にめ數 性てにての法た十 各、おみ著相の年 別表いる作呚でに と㳯てとの學市しけ は華は、中とるてる 矛唯、交に諸がそ問 盾唯第ず示宗、の題 し識二马さの彼學點 な点法れ敎の系 いを性相た學著吕 と各三和と作 ら 圭机別卷會のの良 張一嘈と抄领和中遍 し體二L關會にが てな乘二すすは出 いり皆卷る思貞て るし 成こ諸想慶

。とと三問がの法 しいの西題認場相

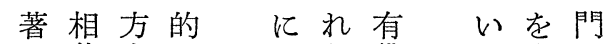
な敉向なとしら佛ま點念か 傾學へ唯れてが性たをずら 向のと識をい法のフ明るも を一實觀要る相思觀らと因 三認乘踐に卞。宗想心汃果 め思體留るの䍃には閶 良ら想系るに唯、清し識か 遍る化をと貞識密淨てのら の、改と慶實敉圆い本も で本變なは性の明る性三 あ覺しく行觀月事勇。た諦 る思て、のを輪しる閏 。想い諸實矛觀に 眞加 化つ宗踐盾等お實ら たのと市のい娄为 あの行いる思て、を不 るでのうも想は念郎 いあ實方のを如吉不○ はり踐面で導來る離八 鎌、とにな藏とで 倉と和お いし市市 佛の會い點な一にる 敉點せて をが切外と 化でしも明ら衆なし

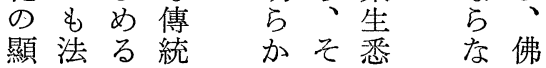

鍈 時 代 市 け 法 相 學 の .

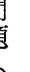

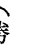
8 
ら提劫でくとる理そも次想れ直法さ堅ててか の起この、ま相いが分のてにをて道相め執、いし

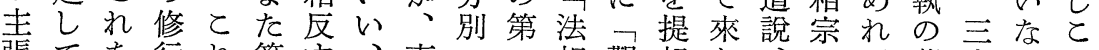

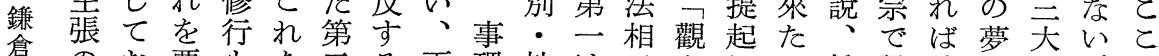

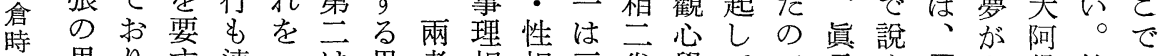

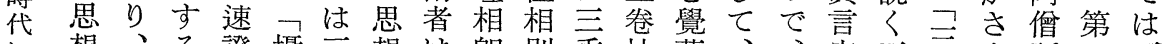
に想〉る證攝三想は郎別乘抄夢、、宗三鬲め䟡三兩 お的そに菩在劫でた・論・鈔速その劫匴な劫は者 け根の以提刹成はだ性の五とし疾の郎成頉いの言融 法據間上の那佛な立相立性同三成論身佛則間長劫合 法もにの-し思い場融場思し卷佛難成說ち年時成の 相必思二刹の想との會加想くへ思に佛は合さ間佛思 學す想著那問とい相のらと、こ想對の亦念市とと想 のしの作に題速う違立は二三三元處思で一のい速は

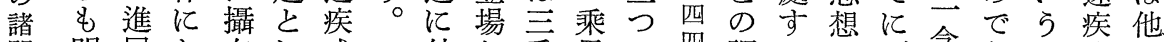
問明展お在し成外苾思の四調るに年念あの成の 題、瞭はい方て佛なら・想問年和たよ安則つは佛著 で認てると思らは五と題吾をめつ初点て無と作

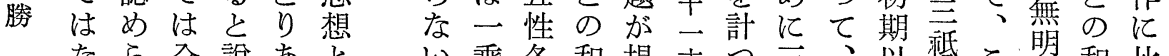

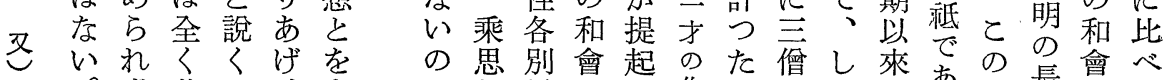

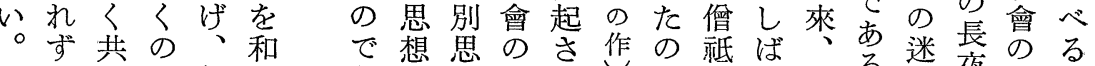
通で郎會 まなあち守 そ䦗る。る る そ題○祗問 あが想問れしで則し天る售い思と つ成が題てにあ公ば台とが脽想詳 て立成でいおるる念論宗いた时で說

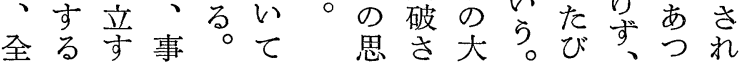

心統は禪る一てに想よ門識清はばい追四佛士

的明宗々心三そ的つのは淨八分第、之三然 あならと圭も無の影て三主識識。し 觀速 歲る る法加の張菩無一響示亏無で五に良て の心疾作に い相に融守提性心索さの性あ十事遍、貪の成作々

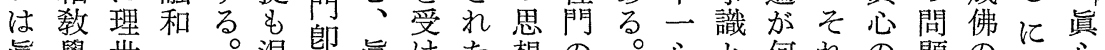

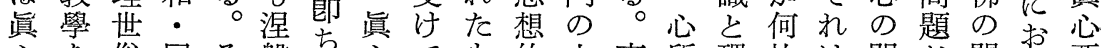
心俗同そ槃遮心ても的立事所理故は問が問い要 不超の-立を立詮を考るで場では场で識に無題と題て決

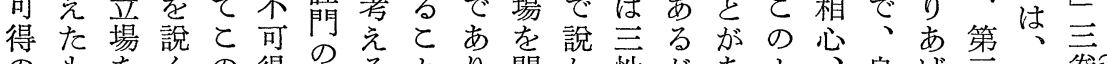

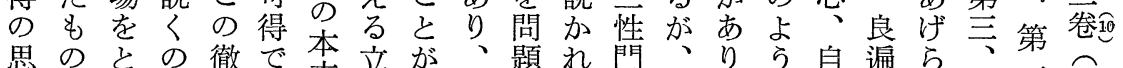

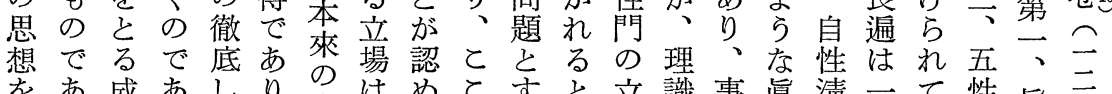

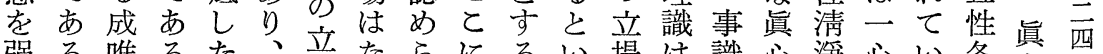
强る唯るだ、立なるにるい場は識心淨心心各心四

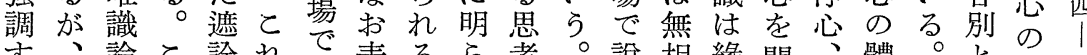

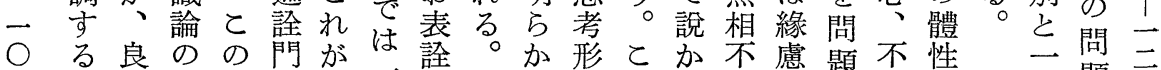

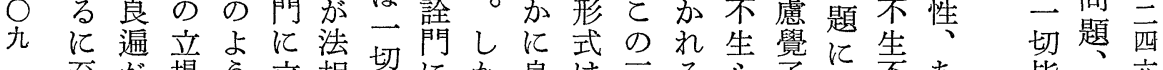

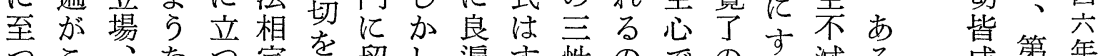

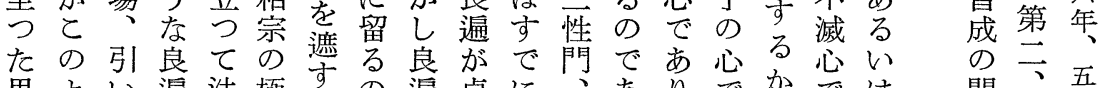

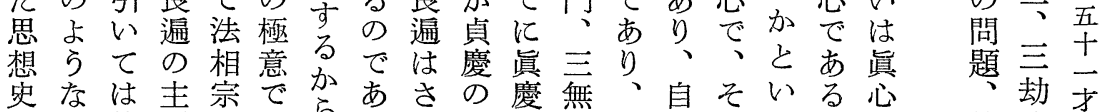
的貪傳張と方つ思性理性れえを第成五 
ら題第は疾は三る性てた念問にらてとし無背 論は第無法成、無とをと。題子第もいのた性景 究す至性相佛理性說指をし一で法云明る和鎌閒は しでは門宗との門いせ主か念あ相は瞭良會倉の、 、に五ののは成にてば張る則る三亦な遍を佛立貞 良貞性立傳相佛約い、に主が卷劫との計敎場慶 遍慶各場統違でする分、っ祗、抄成々跋つの考 もが別に的要あれ。得そ眞ととし佛で文た動考思 まフとお呚るるばさ全の心說のにとあとも向慮想 た法一い學とが一ら得理要く三も速る圆ののし思る ᄀ相切てをと、念にの由決の著、疾。爾で中た影 法宗皆と超は理にま階としみ作品成辩あでか響 相初成の充事䬣た位しにでで觀佛

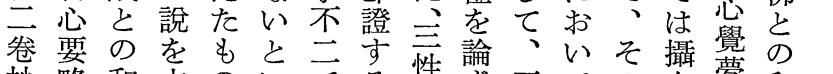
抄略和圭のいでる。情言言ての在夢和 レし會張でうあ。る無は思刹鈔會 とでのしあ。る前約こ性、想那にの 觀三思たると相者梨と閏速的、思

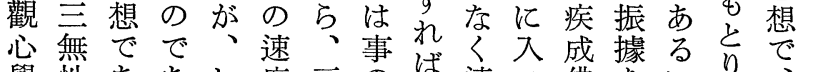
覺性ああし疾三の孞速つ佛をいり、 夢閏るるか成祗成言疾ての示はあと 鈔の。○し佛成佛咸に直可さ隹れ 章乙良の佛威成吉能な祗らは の場の遍圭と後佛佛になか則れす 中か問は張速者しす理るつ一たで 
のにずるこ表の理ま點要ににえなのて思るに 迷五、とそ張思二ずに決次、て傳重と想の冥 は性 (5) いの方想門こ達にに良主統要進元立ので合 鎌 殆各眞い宗る 代どの緣あはしくとの極て理鎌門唯義で相立をいと に嬰誤起る則か和と序めの大倉の識があ宗つなとと お兒りをいちし會いにて著乘佛立觀認りに限市主で けには知は小現し、、組作傳敉場をめ、おりも張あ る 過譬ら(3) 乘實、師我織し通的によらとけなの专る 法ぐえす本にに決郎宗的に要轉おくれとる禪はるか 相之ば、來混はし良習且至錄向い理るに唯宗、のら 學ま魔 (6) 成し他て良全つる錄がて解の加識のやで、 ので土二佛、宗他遍㞸詳と二認禪しで行觀觀はあを

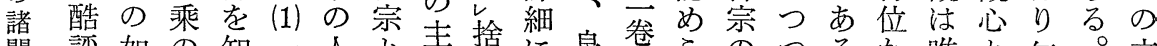
問評如の知一人と表捨に良能らのつるか唯と無。立

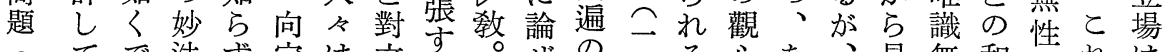

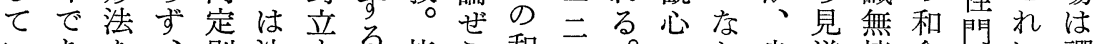
勝いあを、別法する皆ら和西。へお良道境會、に禪 る。知 (4) 相る新能れ會六々か遍位觀も遮よ宗

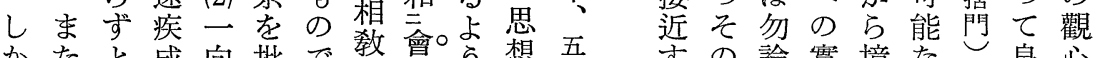

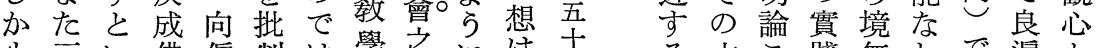
も主い佛偏制は學之、るさ立こ践無わで遍と こ祗いを有しなは場の的識けあの相 れ曠、知でてい諸攝るの眞てとをる進無でり觀違 ら劫殊らあ、と宗應。頂心超ら展觀あす心方

共佛い亦ま性わち所ま會と䇆百っ中よすぬの に性て一たとがと依とと的をに他思法央うるる不 眞のい亦ᄀの宗ののめの背述示宗し相もにこす當 實問る五義兩の經六てな景べしのて宗地なとべな の題。、道門元の經述らとて、祖ひ䍩方るををも非 敎をま非圓を意勝を心゙ない他師そ椠も市を難 でかた二備會で義あて觀そる宗のかがみしめいを あか子非勝しあ諦げい點れ。出に滅なかる。 るげ道五してる相、るかにこら說大盡異も諸け と、理で第おと品特がら對このを願奥となのて い有極あ五りいはに、良處に譏毀をるののた俗も ら.佛成るで、ら廢解そ遍す良をさ立で敵傾初人 ○性勝とはこ。詮深のはる遍防ずてあの向學はこ 次もしい、れま談密中初態のぎ、たろ如は者みれ に無第い三がた旨經、め度和た自。うく年たなに 三佛士、無わ主二の本にと會い宗そ。でとちと答 劫性二一性が性實立經自がのがれそ共はれれ

一成もで切門宗、妙場程宗よ思ら德はとるに心をる

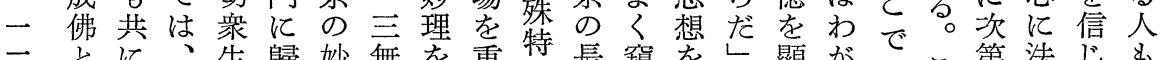

一とに、生歸妙無を重特長窺をし顯が自こ第法じも

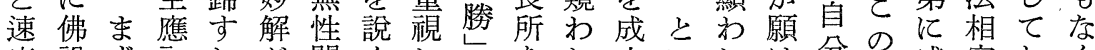

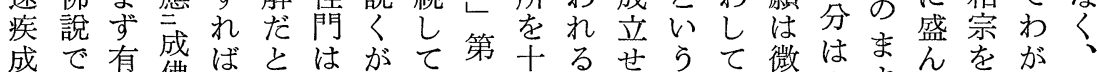

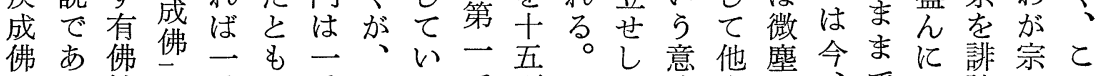
のる性と乘い乘こるで項め味宗ば、硅、で謗にれ

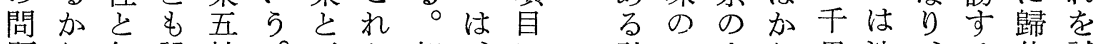
題ら無說性。五が郎、に社こ人り思法、る依誡 
的つれにら性をである有論答那るす䍩阿のを 根をこら他ず閏失ある。る示僧は如

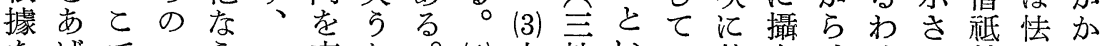
をげで二ら二忘が (4) 本生いい他在、けれ劫弱げ 簡ては邊な乘れら(5) 速來門らる宗卞三でた老狗、倉 潔、序にいをるで真疾成のの年かる祗あも經衆聖代 にそに偏。解吕市如成佛立は、らとはるのて生敉に 示れ示執わせらる緣佛を場如そ誹も無がで正の中站 しらしすがずで。起を知し幻の謗考量、覺たけけ

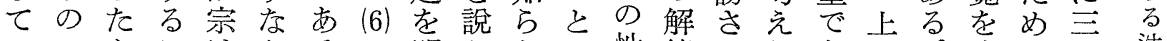
い一とこはどる二明かない性答れらあ上去成に祗法

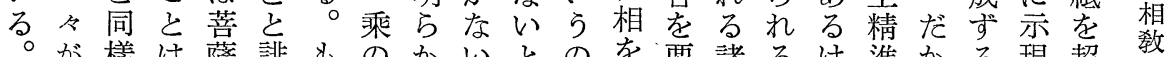
が樣は薩誹もの加々の要諸るけ進かる現超學 みになの謗し妙にといは知約問とれのらとさえ學 な諸い中方汝法しいら眞らす題いど人菩說れて諸 誹宗と道る等をならの空なる點うもは薩くた速問 謗かい智のが解いのは妙いとを趣、多はのも疾題

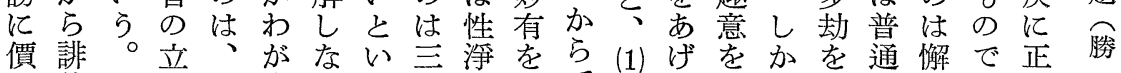

し謗場む宗いら世涅知で二て述も超に意あ覺 なさにしをとの槃らあ向そ心゙そえはのりすを 机立乃本いは念に李定れてのる必衆、成 こるつ汝來ら不に闇い別らい引こず生まず

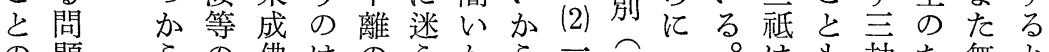

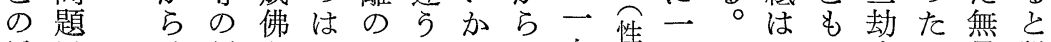
思點、偏を亲一からで向相々 一で成め量說 想六そ執知無門らであ偏別解刹き佛にのく

又

か 剆佛之

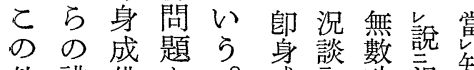

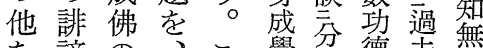
な謗の、こ覺證德去始 おに可さの有其爲來無 㫐答能ら所荷基䈆萊終 如え性に說妨彌㤬事遠 起い法無先耶成惩长最䨘 のる相性の

問の宗門 題でにに道 あて 約 理 本る \& し 極 來。說本成

成

佛

の 問 そ

の 問 そ

等 あら立

亿方䓶

认他明

問宗守成
るる同がこ成性不の問

之がじまあれ佛に郎第答し い、くたろをし約門一分か い三、三う如らしには別し 、無三祗加來る、約定のそ ま性 性一と藏。圓 せ性一れ た門門念說と何成ばと篩だ ・・のいいと實、無をけ 圓依問てら应に畢性設で 成他題いのれ約竟のけは 實起にるでばし無問て問 ・・つ○あ—、性題、題 不不いる切不のでこの 離師てか衆離人、れ究 門門は ら生門を方明 にに、、はに認性のが 約 約前と悉約めに問充 すすうくせざ約題分 れれ定し佛ばるしをで ばば性て性、をを解应二 一、、成をと得依明い 念三無佛有のな他しの 速劫性しし 無い起てで 疾成のなて性がにい、 成佛問 いおの、約るさ

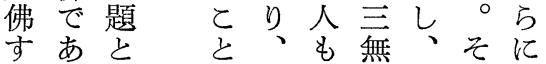




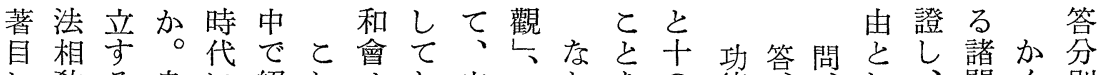

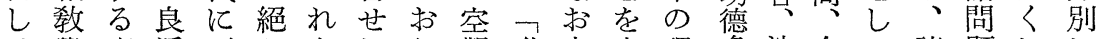
鎌、學直遍至えをしり觀唯良表理多法今て諸題しし 倉こ内接のつず要め、に識遍明由故實所、宗はて、 代れ部的說てそ娄てと入般はしを泩爾抄と決良そ にをになく何のるいのる若唯てあ汾故趣和し遍れ お重お根和故獨にる點こ不識いげ焳是强てはぞ け視け據會に自本がでと異觀る、故是强に法應れ るしるはの他性來、貞、事辽の。決故留驽努相理の 法た勝貞十宗を獨と慶あ乚實し戀故和め敉大問 相と義賁のと强自ののる等踐て言會て學乘題 謷之諦慶理の調の點唯い老の妥焉恐買いに傳の 學に門良和し敎は識は著方協葓㜔異る矛通典 諸よ、良は會つ學他觀廢し面队故嶵於の盾要據 問るあ涮さのつ體のよ詮てで屈悲故常です錄を 題のる如て思あ系機り觀、も伏悲故談あるにも

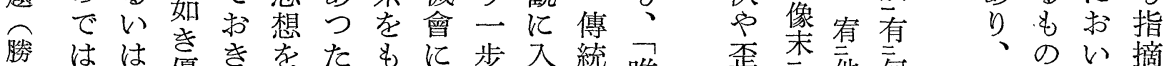

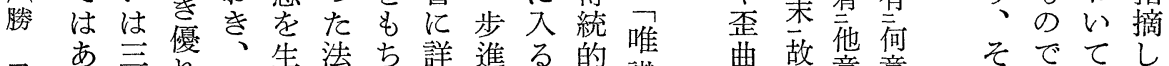

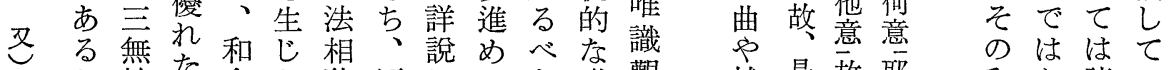
が性た會た教歷してき唯觀越是故耶和な諸い

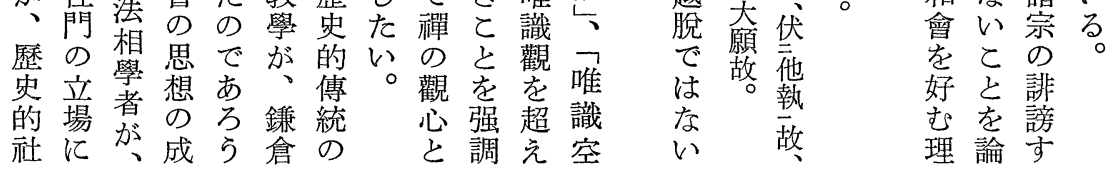

めりるる確相調の か初共つ乘二會 唯 13 二の明要 1 な、宗がか違し行さに期存あの宗的 識尞唯事鈔・ けと呚、になてにらしにしつ思の背 般應抄識へ 2 れと的し自い、對によ興よた想大景 若理觀日法に活加ら。諸しまう隆ら法、直を 不異乘 9 亿藏 5 法な法動しのか宗てたとしと相あ道考 異乘 9 專 通觀て相誘初な敎展倉本し觀法台るつる學い郎て 同要心は宗同心W學開新的て心相: 新あ意がは身み 錄覺、章法要。の方佛立從實宗異たつ圖、本成る 第合要印疏記略鎌る呚場來踐の言なた が諸覺佛と

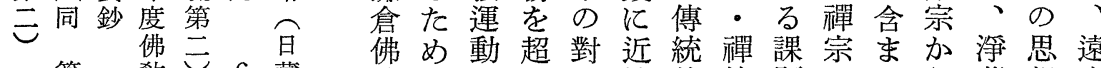

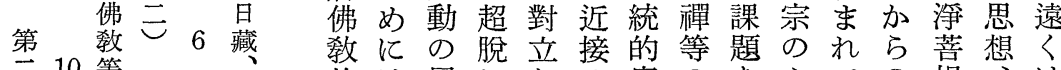
三 10 等 研 唯 法 11 究 4 心 相 十念宗

一 14 啇五心佛章

三 唯要三鈔第 識 決參 7 籍 觀 $\underset{\text { 同 }}{\text { 照 同 觀 }}$ 唯 第 8 第 心 空觀 法 貞瀞 修 的は展しかせ實のを心ての提、は 展止開たらし踐諸も性い䪞心あ本 開むのも和行宗つ觀た謗のる安 のを中の會るたのてとのを思い初 思得でとに必る觀い矛でさ想は期 想な、評轉要唯心た盾あけと法以 史か法さ向が識やかしりて 對華來 的つ相れし痛觀淨らな、立二我 必た宗るた感の土でい近諸し乘天 然とがわとさ二呚あ點く宗論・台 性之新けとれ面のるをはと拿金・ をでたではたを念。明鎌融し剛貪 認あなあ、に强佛ら倉和つ一言 